\title{
SISTEM INFORMASI GEOGRAFIS PEMETAAN PENYANDANG MASALAH KESEJAHTERAAN SOSIAL (PMKS) DI PROVINSI NUSA TENGGARA TIMUR BERBASIS WEB
}

\author{
Junaedy Aryanto Lende, Mira Orisa, Renaldi Primaswara Prasetya \\ Program Studi Teknik Informatika S1, Fakultas Teknologi Industri \\ Institut Teknologi Nasional Malang, Jalan Raya Karanglo km 2 Malang, Indonesia \\ ryanlende256@gmail.com
}

\begin{abstract}
ABSTRAK
Provinsi Nusa Tenggara Timur merupakan salah salu wilayah di Indonesia yang memiliki 22 kota/kabupaten dan kota Kupang sebagai ibu kotanya. Dengan kepadatan penduduk di Nusa Tenggara Timur, berbagai masalah masyarakat muncul di provinsi tersebut, seperti penyandang masalah kesejahteraan sosial yang berdampak bagi penduduk maupun pemerintah daerah. Masalah sosial tersebut seperti kerawanan sosial ekonomi, ketunasosialan, keterlantaran, kecacatan, penyimpangan perilaku, keterpencilan, eksploitasi, dan kerentanan sosial. Namun, sejauh ini belum ada pemetaan mengenai penyandang masalah kesejahteraan sosial berbasis Sistem Informasi Geografis. Dalam penelitian ini, pemetaan penyandang masalah kesejahteraan sosial berbasis Sistem Informasi Geografis dibuat dalam bentuk website Sistem Informasi Geografis ini dikembangkan menggunakan software Quantum GIS untuk pembuatan peta, Sublime Text 3 untuk proses codding, MySQL sebagai database, proses visualisasi wilayah menggunakan GeoJSON dan visualisasi peta menggunakan Leaflet. Sistem yang dibangun meliputi data $22 \mathrm{kota} /$ kabupaten dengan 26 kategori penyandang masalah kesejahteraan sosial berdasarkan Peraturan Menteri Sosial Republik Indonesia No. 8 Tahun 2012. Hasil pengujian dari Sistem Informasi Geografis Pemetaan Penyandang Masalah Kesejahteraan Sosial di Provinsi Nusa Tenggara Timur Berbasis Web yang berhasil dikembangkan menunjukan hasil yang cukup sukses. Hal itu dibuktikan dengan hasil pengujian Pengguna yang mayoritas pengguna menilai website yang dibuat telah memenuhi kebutuhan, pengujian fungsional secara Blackbox pada desktop dengan menggunakan browser Chrome, Edge dan Opera yang menunjukkan seluruh fitur Sistem Informasi Geografis berjalan sesuai dengan fungsinya. Semua fungsi dari sistem berjalan sesuai dengan yang diinginkan.
\end{abstract}

\section{Kata Kunci : PMKS, SIG, Web-GIS, Leaflet, GeoJson, Nusa Tenggara Timur}

\section{PENDAHULUAN}

Penyandang Masalah Kesejahteraan Sosial (PMKS) adalah masalah yang tidak ada habishabisnya di Indonesia. Dikutip dari situs Dinas Sosial Provinsi Riau http://dinsos.riau.go.id/, PMKS merupakan individu atau kelompok yang memiliki suatu kesulitan dikarenakan adanya gangguan dalam permasalahan sosial. Hal tersebut mengakibatkan kurang mampunya individu atau kelompok tersebut dalam melakukan fungsi sosial dan hubungan dengan lingkungannya serta kurang mampu dalam pemenuhan kebutuhan jasmani maupun rohani secara normal. Menurut Kementrian Sosial Republik Indonesia, saat ini tercatat ada 26 jenis PMKS yang berbeda-beda.

Di Provinsi Nusa Tenggara Timur terdapat 22 kota/kabupaten dan kota Kupang sebagai ibukota provinsi. Dari 26 kategori PMKS di atas masih banyak masyarakat di Provinsi Nusa Tenggara Timur dengan kebutuhan dasar seperti pangan, sandang, tempat tinggal, dan interaksi sosial yang belum terpenuhi. Hal ini dikarenakan kurangnya bantuan sosial dari pemerintah khususnya pemerintah daerah. Di samping itu, juga terjadi kerawanan sosial ekonomi, ketunasosialan, keterlantaran, kecacatan, penyimpangan perilaku, keterpencilan, eksploitasi, dan kerentanan sosial masyarakat Provinsi Nusa Tenggara Timur.

Sejauh ini PMKS di provinsi nusa tenggara timur masih sebatas tabel-tabel yang tidak terstruktur perkabupaten. Padahal, dewasa ini teknologi informasi dapat dipergunakan untuk menggambarkan pemetaan informasi publik, termasuk PMKS. Salah satu teknologi yang dapat digunakan untuk menggambarkan pemetaan informasi publik adalah Sistem Informasi Geografis, yaitu sistem informasi geografis berbasis web yang mudah diakses oleh siapa saja.

Untuk menjawab masalah mengenai PMKS tersebut, peneliti bertujuan untuk membuat sistem informasi geografis yang mengklarifikasikan jumlah penyandang masalah kesejahteraan sosial untuk menunjukan wilayah kota/kabupaten yang perlu mendapat perhatian khusus dari pemerintah terutama di Provinsi Nusa Tenggara Timur. Dengan adanya penelitian mengenai Sistem Informasi Geografis pemetaan Penyandang Masalah Kesejahteraan Sosial (PMKS) di Provinsi Nusa Tenggara Timur diharapkan dapat memberikan gambaran persebaran PMKS kepada pemerintah di samping informasi jumlah PMKS kepada masyarakat. 


\section{TINJAUAN PUSTAKA}

\subsection{Penelitian Terdahulu}

Budiarto pada tahun 2019 melakukan penelitian Sistem Informasi Geografis Pondok Pesantren dirancang dengan menggunakan ArcGis dan Qgis serta bahasa pemrograman php dan html dimana sistem yang bermanfaat untuk masyarakat umum, khususnya Departemen Agama dalam mendapatkan informasi tentang pondok pesantren, serta fasilitas pondok pesantren yang terdapat di wilayah Kota Malang[1].

Kemudian pada tahun yang sama Arbina melakukan penelitian Sistem Infomasi Geografis Pemetaan Daerah Perkebunan. Dan Komoditas Hasil Panen Provinsi Kalimantan Tengah. Penelitian ini memberikan manfaat kepada Dinas Perkebunan Kalimantan Tengah dapat mengelola data lapangan secara lebih cepat dan terperinci dengan baik dan mendukung pemerintahan daerah dalam menganalisis data-data komoditi perkebunan perlu di kembangkan suatu sistem yang memaksimalkan pemetaan tiap tanah di provinsi Kalimantan Tengah. Sistem informasi geografis ini dapat mengetahui banyaknya kategori daerah perkebunan yang masih belum di pergunakan dapat di jadikan acuan bagi rakyat atau pemerintah mengelola lahan sehingga mengasilkan lapangan pekerja bagi masyarakat setempat[2].

Pada akhir tahun 2019 Pradana melakukan penelitian mengenai Sistem Informasi Geografis Penggunaan Lahan dan Produksi Tanaman Pangan Kabupaten Kediri Jawa Timur, tujuan sistem ini dibangun untuk mempermudah masyarakat melihat lahan jenis tanaman pangan yang sudah ada maupun yang belum ada di suatu kecamatan tersebut. Penerapan sistem informasi geografis ini bermanfaat untuk memberikan informasi letak wilayah-wilayah kecamatan dari Kabupaten Kediri serta mengetahui beberapa lahan jenis tanaman yang terdapat di Kecamatan tersebut, dan memberikan informasi produksi hasil panennya dari tiap-tiap kecamatan[3].

Pada akhir tahun 2018 Pratama melakukan penelitian serupa penelitiannya menerapkan Location based service yang digunakan untuk melakukan fungsi navigasi yang mengarahkan pengguna ke lokasi fasilitas kesehatan. Lokasi fasilitas ditampilkan kedalam peta dan penanda dimana data koordinat setiap fasilitas sudah dimasukkan kemudian Informasi lengkap dari setiap fasilitas ditampilkan[4].

Tahun 2018 Pranoto dan kawan-kawan melakukan penelitian mengenai pemetaan berbasis website untuk pusat kesehatan masyarakat di wilayah Kabupaten Malang. Penelitian tersebut memetakan pusat kesehatan yang ada dikabupaten malang dalam bentuk website[5].

Pada Tahun 2018 Julkifli melakukan penelitian mengenai Sistem Informasi Geografis Kecamatan Woja Kabupaten Dompu Nusa Tenggara Barat. Sistem yang dirancang dengan menggunakan ARTVIEW dan Google Maps API serta bahasa pemrograman $P H P$ dan $H T M L$ penelitian ini memberikan manfaat kepada masyarakat dalam mendapatkan informasi tentang jumlah penduduk, jumlah ternak besar, pendidikan, serta fasilitas kesehatan yang terdapat di wilayah Kecamatan Woja[6].

\subsection{Penyandang Masalah Kesejahteraan Sosial (PMKS)}

Penyandang Masalah Kesejahteraan Sosial (PMKS) adalah seseorang atau keluarga yang karena suatu hambatan, kesulitan atau gangguan tidak dapat melaksanakan fungsi sosialnya dan karenanya tidak dapat menjalin hubungan yang serasi dan kreatif dengan lingkungannya sehingga tidak dapat memenuhi kebutuhan hidupnya (jasmani, rohani dan sosial) secara memadai dan wajar[7].

Berdasarkan Peraturan Menteri Sosial Republik Indonesia No. 8 Tahun 2012, saat ini Penyandang Masalah Kesejahteraan Sosial (PMKS) tercatat memiliki 26 jenis sebagai berikut, (Anak Balita Terlantar, Anak Terlantar, Anak yang Berhadapan Dengan Hukum, Anak Jalanan, Anak Dengan Kedisabilitasan, Anak yang Menjadi Korban Tindak Kekerasan, Anak Yang Memerlukan Perlindungan Khusus, Lanjut Usia Terlantar, Penyandang Disabilitas, Tuna Susila, Gelandangan, Pengemis, Pemulung, Kelompok Minoritas, Bekas Warga Binaan Lembaga Pemasyarakatan (BWBLP), Orang Dengan HIV/AIDS (ODHA), Korban Penyalahgunaan NAPZA, Korban Trafficking, Korban Tindak Kekerasan, Pekerja Migran Bermasalah Sosial (PMBS), Korban Bencana Alam, Perempuan Rawan Sosial Ekonomi, Fakir Miskin, Keluarga Bermasalah Sosial Psikologis, Komunitas Adat Terpencil)[8]

Dinas Sosial Provinsi Nusa Tenggara Timur sebagai Satuan Kerja Perangkat Daerah (SKPD) wajib melaksanakan tugas pokok dalam penanganan terhadap Penyandang Masalah Kesejahteraan Sosial (PMKS) melalui usaha bersama pemerintah dan masyarakat. Permasalahan sosial tentunya haruslah ditangani melalui suatu pembangunan kesejahteraan sosial. Agar berhasilnya pembangunan tersebut diperlukan suatu perencanaan yang tepat. Disadari pula bahwa pembangunan kesejahteraan sosial memerlukan dukungan dari masyarakat. Usaha dalam pembangunan dan peningkatan kesejahteraan sosial di Nusa Tenggara Timur merupakan tanggungjawab pemerintah dan masyarakat. Masyarakat berperan sebagai pelaksana utama, sedangkan pemerintah adalah menetapkan regulasi dan memberikan fasilitas[9].

\subsection{Sistem Informasi Geografis}

Sistem Informasi Georafis atau Georaphic Information Sistem (GIS) merupakan suatu sistem informasi yang berbasis komputer, dirancang untuk bekerja dengan menggunakan data yang memiliki informasi spasial (bereferensi keruangan). Sistem ini meng-capture, mengecek, mengintegrasikan, 
memanipulasi, menganalisa, dan menampilkan data yang secara spasial mereferensikan kepada kondisi bumi. Teknologi SIG mengintegrasikan operasioperasi umum database, seperti query dan analisa statistik, dengan kemampuan visualisasi dan analisa yang unik yang dimiliki oleh pemetaan. Kemampuan inilah yang membedakan SIG dengan Sistem Informasi lainya yang membuatnya menjadi berguna berbagai kalangan untuk menjelaskan kejadian, merencanakan strategi, dan memprediksi apa yang terjadi [10].

Sistem Informasi Geografis dapat dimanfaatkan untuk mempermudah dalam mendapatkan data-data yang telah diolah dan tersimpan sebagai atribut suatu lokasi atau obyek. Data-data yang diolah dalam SIG pada dasarnya terdiri dari data spasial dan data atribut dalam bentuk digital. Sistem ini merelasikan data spasial (lokasi geografis) dengan data non spasial, sehingga para penggunanya dapat membuat peta dan menganalisa informasinya dengan berbagai cara. SIG merupakan alat yang handal untuk menangani data spasial, dimana dalam SIG data dipelihara dalam bentuk digital sehingga data ini lebih padat dibanding dalam bentuk peta cetak, tabel, atau dalam bentuk konvensional lainya yang akhirnya akan mempercepat pekerjaan dan meringankan biaya yang diperlukan [10].

\subsection{Pemetaan}

Pemetaan adalah ilmu yang mempelajari kenampakan muka bumi yang menggunakan suatu alat dan menghasilkan informasi yang akurat. Dengan kata lain, pemetaan dan ilmu geografi itu sama karena sama-sama membahas sesuatu yang berada di dalam atau di atas bumi selama hal tersebut mempengaruhi permukaan bumi[11].

\subsection{WebGis}

Web-GIS merupakan Sistem Informasi Geografi berbasis web yang terdiri dari beberapa komponen yang saling terkait. Web-GIS merupakan gabungan antara design grafis pemetaan, peta digital dengan analisis geografis, pemrograman komputer, dan sebuah database yang saling terhubung menjadi satu bagian web desain dan web pemetaan[12].

WebGIS sendiri dapat diakses secara online melalui internet/web. Pada konfigurasi WebGIS ada server yang berfungsi sebagai MapServer yang bertugas memproses permintaan peta dari client dan kemudian mengirimkannya kembali ke client. Dalam hal ini pengguna/client tidak perlu mempunyai software GIS, hanya menggunakan internet browser seperti Internet Explorer, Mozilla Fire Fox, atau Google Chrome untuk mengakses informasi GIS yang ada di server[13].

\subsection{Leaflet}

Leaflet.js adalah perpustakaan OpenSource JavaScript yang membantu pembuatan peta pada halaman web mudah. Menjadi Open Source berarti bahwa kode dapat dengan mudah untuk dilihat cara kerjanya, siapa pun dapat menggunakannya dan yang lebih penting siapa pun dapat berkontribusi kembali ke proyek dengan perbaikan kode. Tujuannya adalah agar mudah digunakan, fokus pada kinerja dan kegunaan. Leaflet juga dibangun untuk menggunakan plugin yang memperluas fungsionalitas. Leaflet memiliki API yang sangat baik yang didokumentasikan dengan baik, sehingga tidak ada misteri untuk menggunakannya berhasil dalam berbagai situasi. Perusahaan yang telah disebut-sebut sebagai menggunakan Leaflet termasuk Flickr, foursquare, craigslist, Data.gov, IGN, Wikimedia, OSM, Meetup, WSJ, Mapbox, Cloudmade, CartoDB dan GIS Cloud. Selain itu Leaflet menyediakan fungsionalitas untuk menambahkan penanda, popup, garis overlay dan bentuk, menggunakan beberapa lapisan, zoom, pan, tapi ini hanya fitur inti Leaflet. Salah satu kekuatan yang signifikan dari Leaflet adalah kemampuan untuk memperluas fungsionalitas dari script dengan plugin dari pihak ketiga. Pada saat penulisan ada lebih dari 80 plugin terpisah yang memungkinkan fitur seperti overlay heatmap, animating markers, loading csv files of data, drawing complex shapes, measuring distance, manipulating layers dan displaying coordinates[14].

\subsection{GeoJSON}

JSON (JavaScript Object Notation) adalah format pertukaran data yang ringan, mudah dibaca dan ditulis oleh manusia, serta mudah diterjemahkan dan dibuat (generate) oleh komputer. Format ini dibuat berdasarkan bagian dari Bahasa Pemprograman JavaScript, Standar ECMA-262 Edisi ke-3 - Desember 1999. JSON merupakan format teks yang tidak bergantung pada bahasa pemprograman apapun karena menggunakan gaya bahasa yang umum digunakan oleh programmer keluarga C termasuk C, C++, C\#, Java, JavaScript, Perl, Python dll. Oleh karena sifat-sifat tersebut, menjadikan JSON ideal sebagai bahasa pertukaran data[15].

GeoJSON adalah format untuk pengkodean berbagai struktur data geografis. Objek GeoJSON dapat mewakili geometri, fitur, atau kumpulan fitur. GeoJSON mendukung tipe geometri berikut: Point, LineString, Polygon, MultiPoint, MultiLineString, MultiPolygon, dan GeometryCollection. Fitur di GeoJSON berisi objek geometri dan properti tambahan, dan koleksi fitur. 9 Struktur data GeoJSON yang merupakan objek (dalam istilah JSON)[16].

\subsection{Quantum GIS}

Quantum GIS (QGIS) adalah sebuah aplikasi Geographic Information System (GIS) sumber terbuka dan lintas platform yang dapat dijalankan di sejumlah sistem operasi termasuk Linux. QGIS juga memiliki kemampuan untuk bekerjasama dengan paket aplikasi komersil terkait. QGIS menyediakan semua fungsionalitas dan fitur-fitur yang dibutuhkan 
oleh pengguna GIS pada umumnya. Menggunakan plugins dan fitur inti (core features) dimungkinkan untuk menvisualisasi (meragakan) pemetaan (maps) untuk kemudian diedit dan dicetak sebagai sebuah peta yang lengkap. Penguna dapat menggabungkan data yang dimiliki untuk dianalisa, diedit dan dikelola sesuai dengan apa yang diinginkan [17].

Dalam QGIS, penyusunan kerja dibuat menggunakan project. Project mengandungi semua dokumen yang digunakan untuk menghasilkan kerja atau proses yang diurus. Dalam QGIS terdapat tiga jenis dokumen: Maps, Attribute Table dan Composer. Setiap satu mempunyai fungsi yang berbeda serta menu, buttons dan tools yang tersendiri [17].

\section{METODE PENELITIAN}

\subsection{Arsitektur Sistem}

Pada gambar 1 dimulai dari mengumpulkan data berupa data spasial dan data atribut, selanjutnya dilakukan proses digitasi menjadi sebuah file geojson yang sudah memiliki data spasial dan data atribut, kemudian data tersebut akan ditampilkan kedalam web, dan selanjutnya dilakukan proses analisis manual dari output peta tersebut.

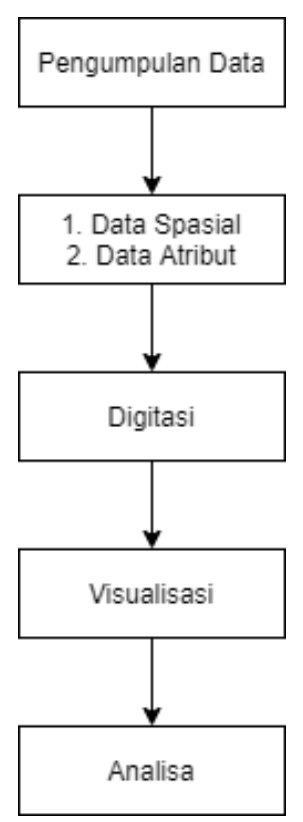

Gambar 1 Arsitektur Sistem

\subsection{Blok Diagram Sistem}

Blok diagram adalah diagram dari sebuah sistem, dimana terdapat input, proses dan output. Pada input terdapat data spasial Kota/Kabupaten, data atribut Kota/Kabupaten, data PMKS. Pada proses terdapat analisis data spasial, analisis data atribut, analisis data PMKS, dan pada output terdapat peta Provinsi Nusa Tenggara Timur, informasi Kota/Kbaupaten dan informasi PMKS.

Proses kerja blok diagram sistem informasi geografis ditunjukkan pada Gambar 2.

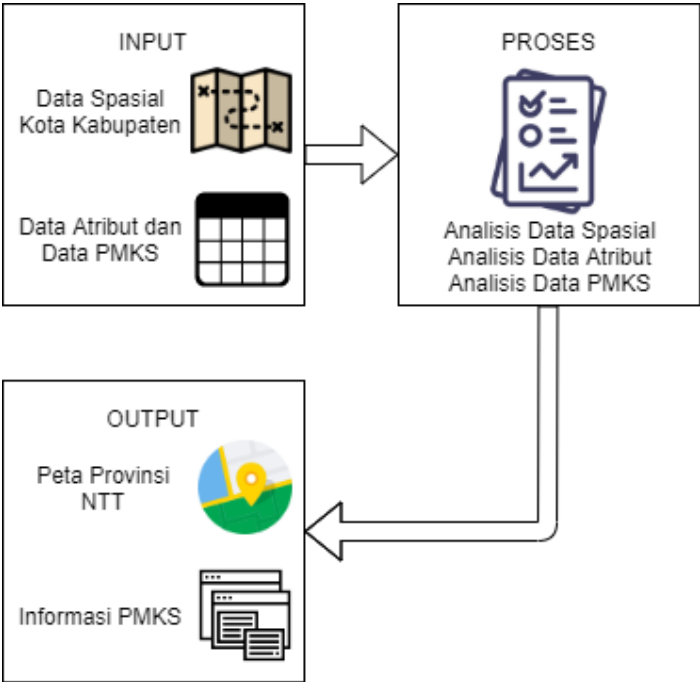

Gambar 2 Blok Diagram Sistem

\subsection{Flowchart SIG}

Berikut ini merupakan flowchart SIG dari system informasi geografis pemetaan penyandang masalah kesejahteraan sosial di provinsi nusa tenggara timur, seperti ditunjukkan pada gambar 3 .

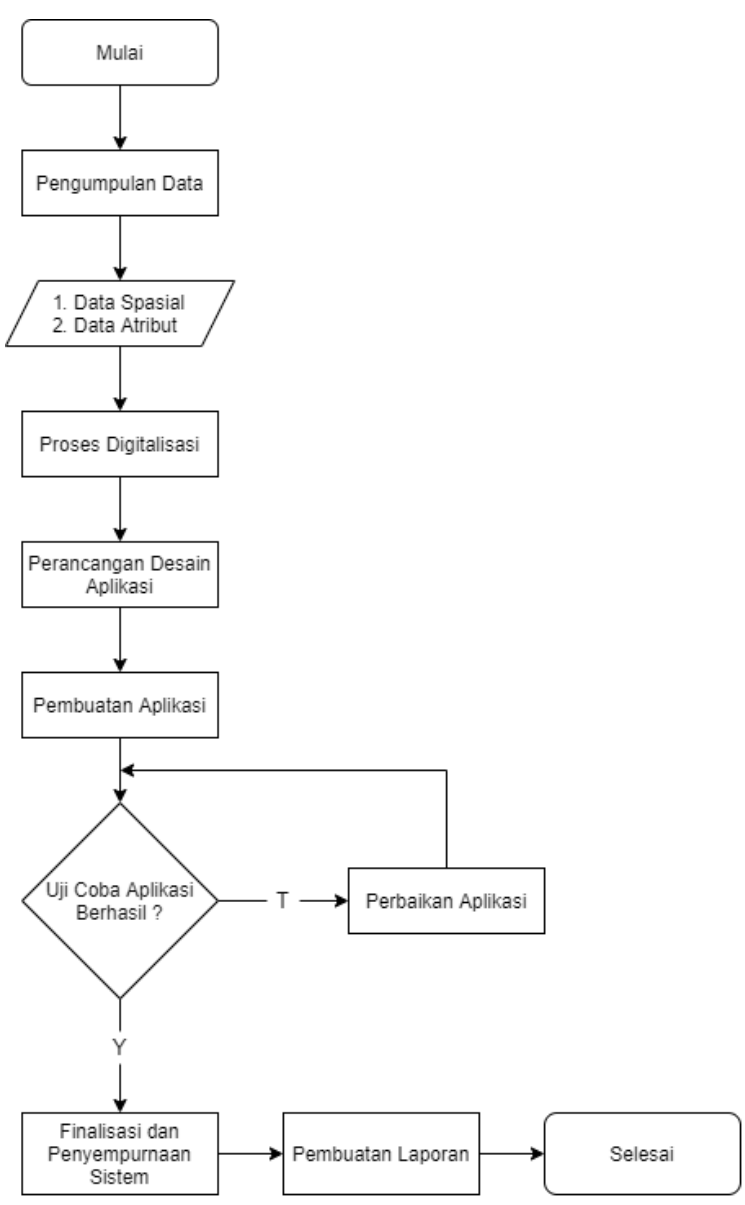

Gambar 3. Flowchart SIG 
Flowchart SIG pada gambar 3 dimulai dengan mengumpulkan data berupa data spasial dan data atribut, kemudian dilakukan proses digitasi menjadi sebuah file geojson yang sudah memiliki data spasial dan data atribut, selanjutnya melakukan perangcangan atau desain website dan pembuatan website. Berikutnya dilakukan uji coba website yang telah dibuat untuk dianalisis guna memperbaiki kekurangan yang ada. Selanjutnya masuk pada tahap finalisasi dan penyempurnaan sistem, pada tahap ini dilakukan perbaikan dan penyempurnaan desain dan kinerja sistem sesuai dengan hasil analisis. Tahap terakhir yaitu pembuatan laporan, pembuatan laporan ini berisi tentang indikator-indikator dari tujuan apakah sudah terpenuhi atau belum. Selain itu terdapat dokumentasi serta kesimpulan dari kegiatan yang telah dilakukan.

\subsection{Flowchart Sistem}

Bagan alir sistem (flowchart sistem) adalah bagan-bagan yang mempunyai arus dan menggambarkan langkah-langkah penyelesaian suatu masalah yang dituliskan dalam simbol-simbol tertentu. Adapun flowchart sistem yang dibuat untuk menggambarkan alur dari aplikasi ini seperti pada gambar 4 dibawah ini.

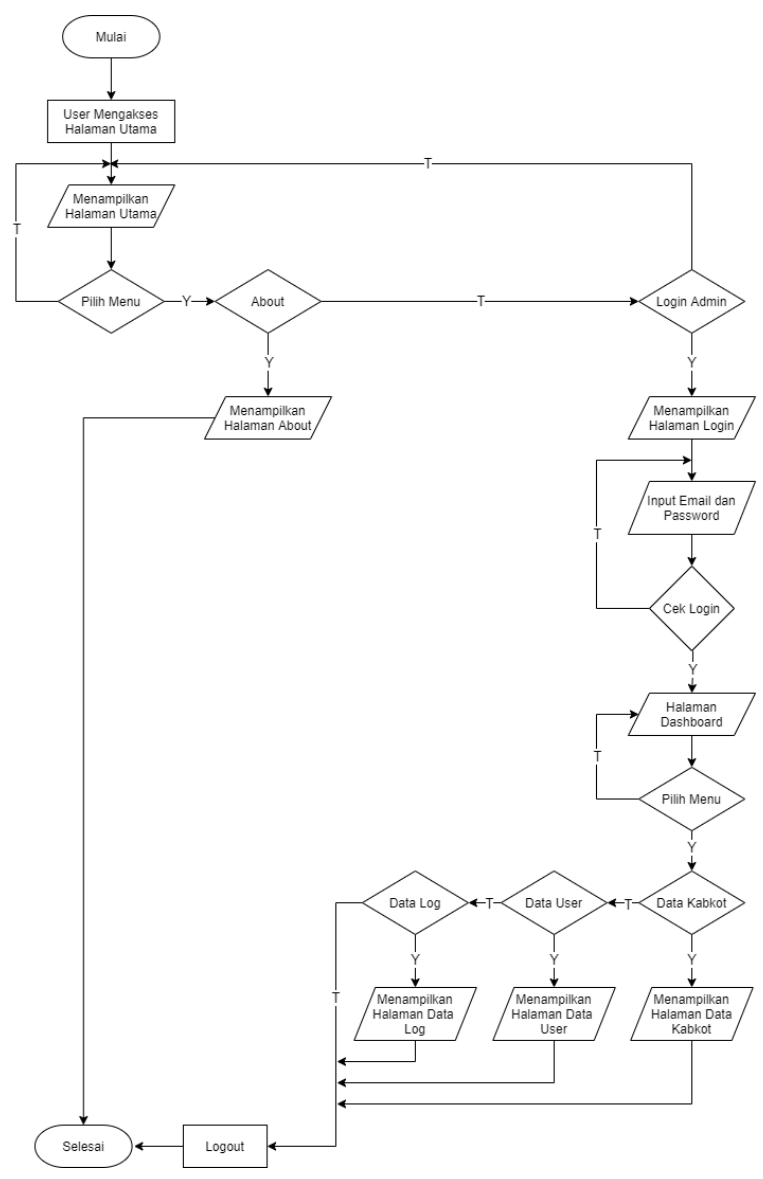

Gambar 4 Flowchart Sistem
Pada gambar 4 flowchart sistem dimulai dengan user mengakses halaman utama selanjutnya menampilkan halaman utama dari web, kemudian user memilih menu jika user tidak memilih menu maka akan tetap pada halaman utama, jika iya maka user akan memilih menu diantaranya menu about dan login admin, jika user memilih halaman about maka akan menampilkan informasi pada halaman about, jika tidak memilih halaman about maka akan masuk ke halaman login admin, selanjutnya pada login admin akan diinputkan email dan password, kemudian dilakukan cek login, jika email dan password salah maka akan kembali melakukan input email dan password dan jika benar maka admin akan masuk ke dalam halaman dashboard, selanjutnya akan memilih menu data kabkot maka akan menampilkan data kabkot, jika tidak selanjutnya memilih menu data user dan akan menampilkan data user, jika tidak selanjutnya memilih menu data log dan akan menampilkan data log, kemudian jika maka akan keproses logout dan program selesai.

\subsection{Data Flow Diagram (DFD)}

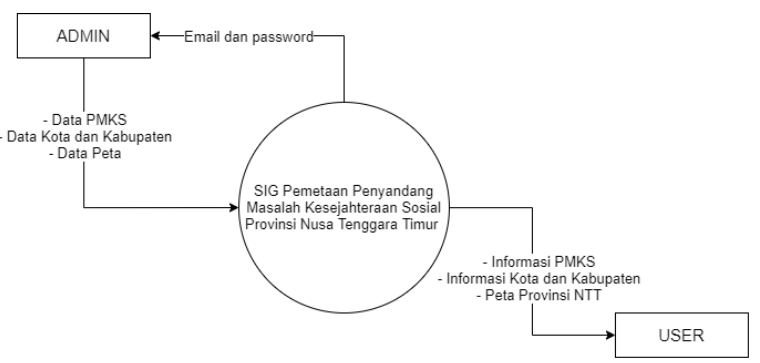

Gambar 5 Data Flow Diagram (DFD)

DFD pada gambar 5 menjabarkan alur dari sistem Informasi Geografis Penyandang Masalah Kesejahteraan Sosial, Awal terdapat halaman utama dari sistem informasi geografis selanjutnya menginput username dan password agar masuk kehalaman admin, kemudian admin menginput data PMKS, data Kota dan Kabupaten serta data peta. Selanjutnya user menerima informasi mengenai Sistem Informasi Geografis Penyandang Masalah Kesejahteraan Sosial di Provinsi Nusa Tenggara Timur Berbasis Web.

\subsection{Entity Relationship Diagram (ERD)}

Pada gambar 3.7 Entity Relationship Diagram dari sistem informasi geografis penyandang masalah kesejahteraan sosial diatas diketahui pada entitas yaitu PMKS dengan 14 atribut yang terdapat relasi yaitu menampilkan antara PMKS ke Kota dan Kabupaten yang atributnya berjumlah 5 dan terdapat juga relasi yaitu di kelola antara PMKS ke Admin yang memiliki 4 atribut. 


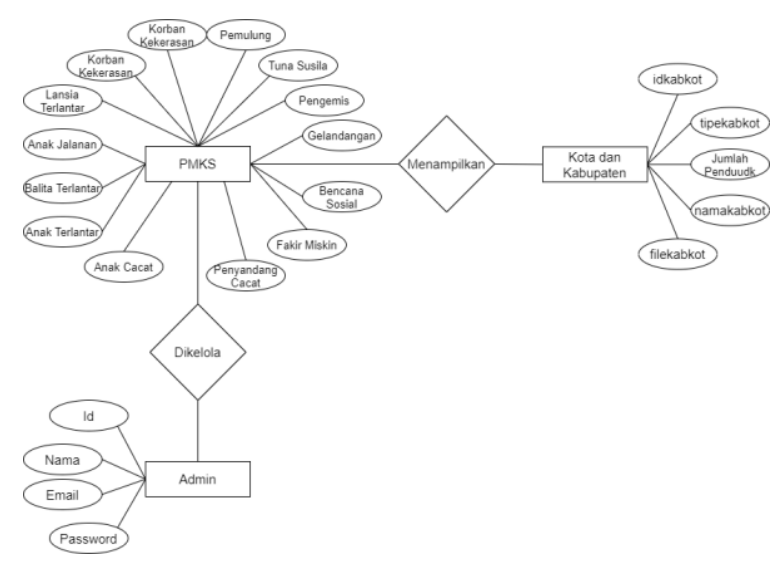

Gambar 6 Entity Relationship Diagram

\section{HASIL DAN PEMBAHASAN}

4.1. Hasil

Hasil dari program untuk tampilan pada halaman Home dapat ditunjukkan dalam Gambar 7.

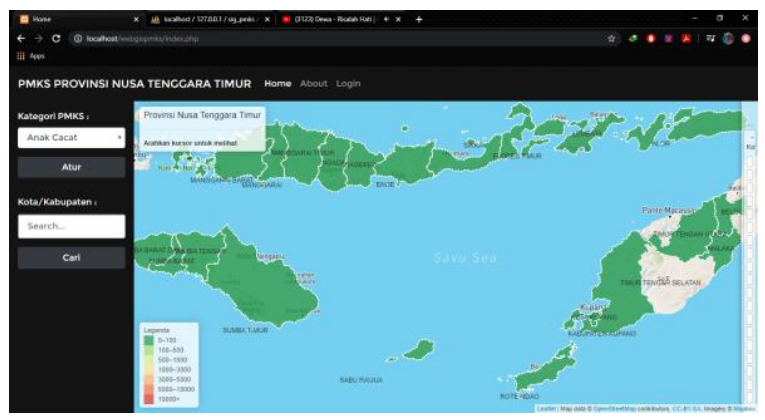

Gambar 7 Halaman Home

Hasil dari program untuk tampilan pada panel layer dapat ditunjukkan dalam Gambar 8.

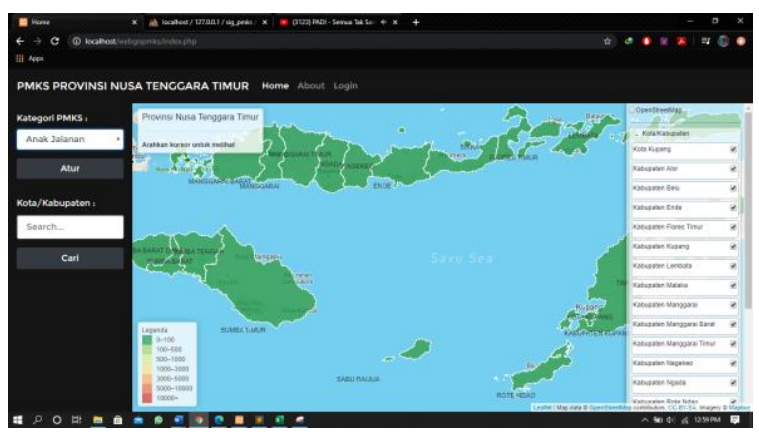

Gambar 8 Tampilan Panel Layer

Hasil dari program untuk tampilan Cari Peta dapat ditunjukkan dalam Gambar 9.

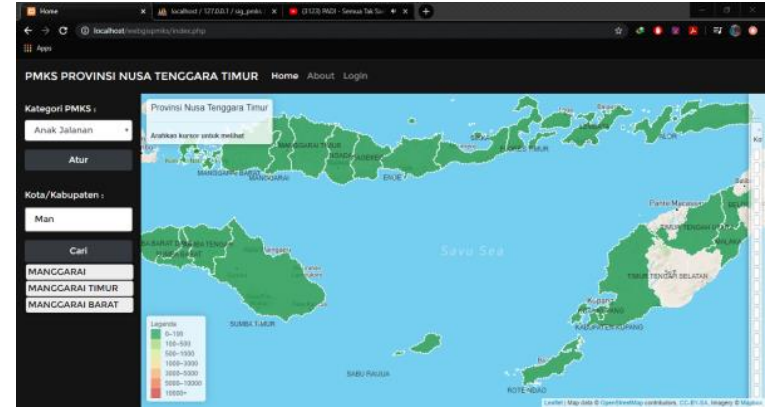

Gambar 9 Tampilan Cari Peta

Hasil dari program untuk tampilan pada halaman about dapat ditunjukkan dalam Gambar 10.

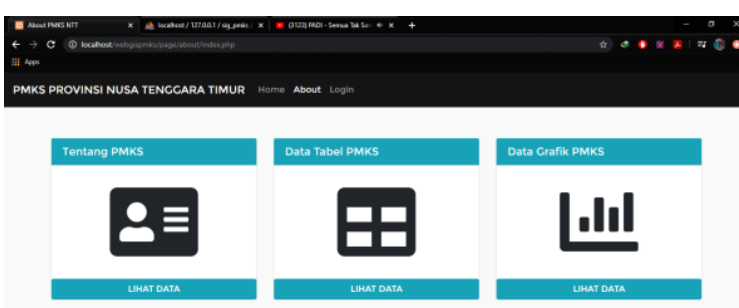

Gambar 10 Tampilan About

Hasil dari program untuk tampilan halaman Data Tabel dapat ditunjukkan dalam Gambar 11.

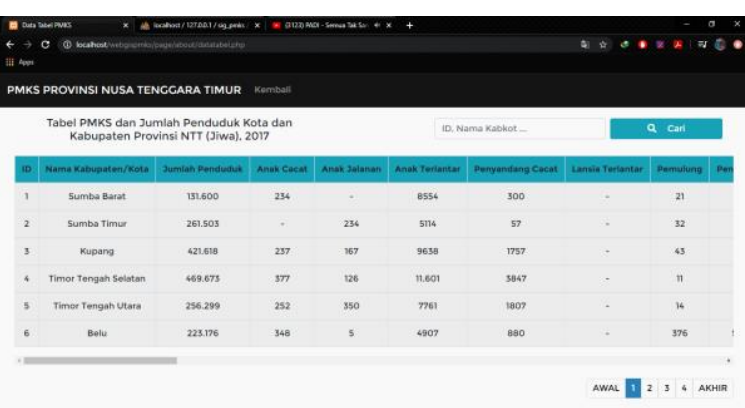

Gambar 11 Tampilan data tabel

Hasil dari program untuk tampilan pada halaman Data Grafik dapat ditunjukkan dalam Gambar 12.

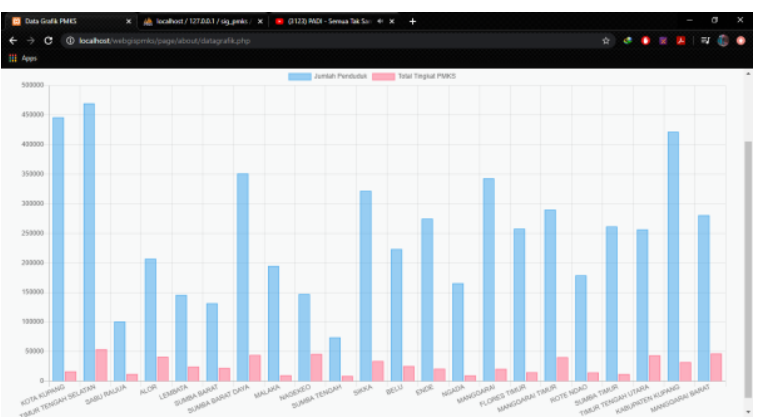

Gambar 12 Tampilan data grafik 
Hasil dari program untuk tampilan pada halaman Login dapat ditunjukkan dalam Gambar 13.

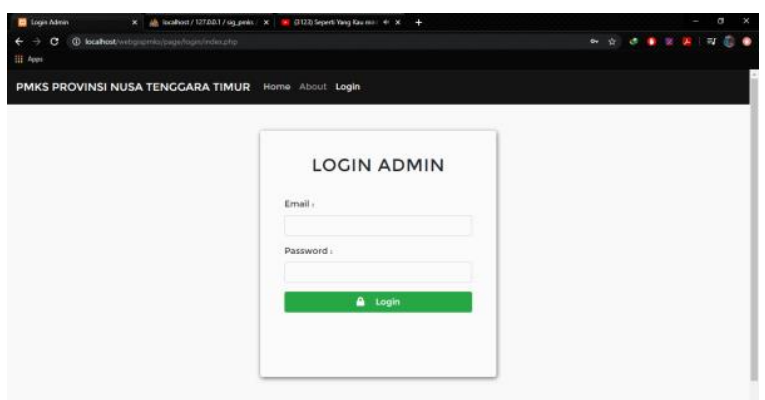

Gambar 13 Halaman Login

Hasil dari program untuk tampilan pada halaman Dashboard dapat ditunjukkan dalam Gambar 14.

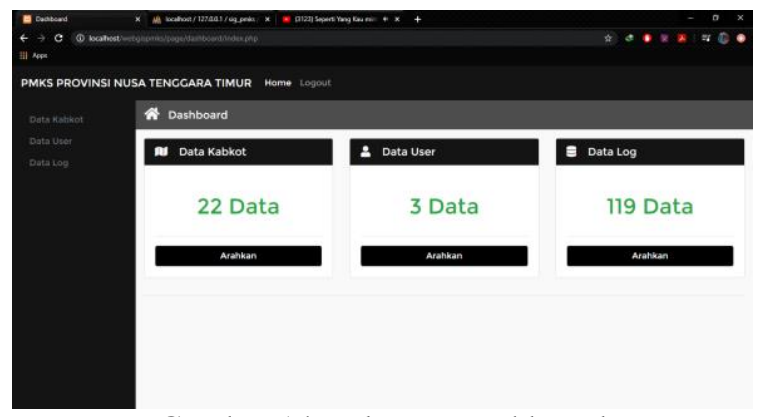

Gambar 14 Halaman Dashboard

Hasil dari program untuk tampilan halaman Data User dapat ditunjukkan dalam Gambar 15.

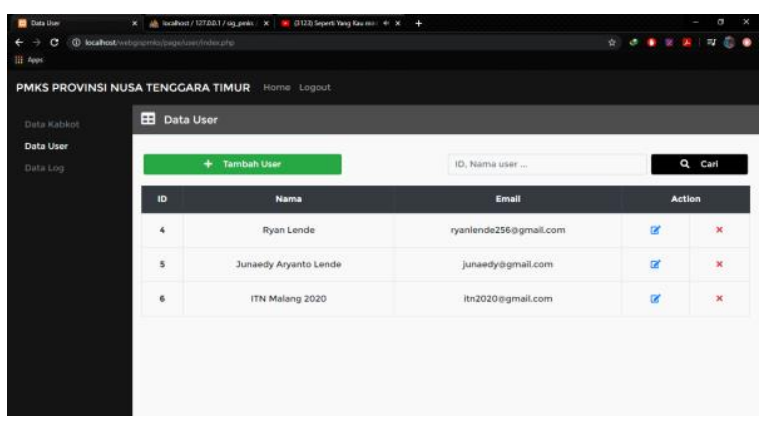

Gambar 15 Halaman Data User

Hasil dari program untuk tampilan pada halaman Tambah Data User dapat ditunjukkan dalam Gambar 16.

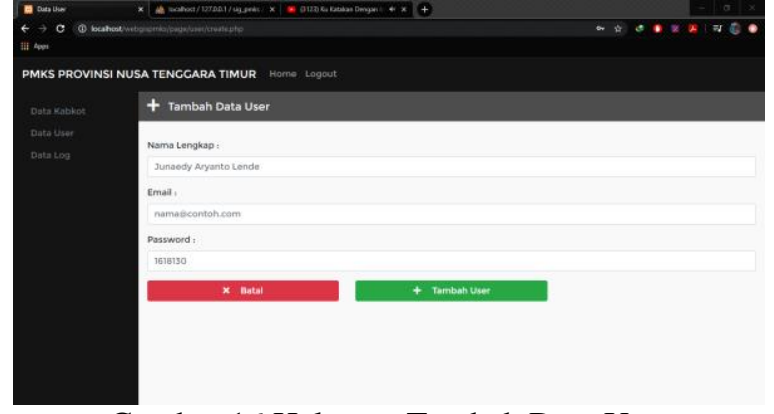

Gambar 16 Halaman Tambah Data User

Hasil dari program untuk tampilan pada halaman Edit Data User dapat ditunjukkan dalam Gambar 17.

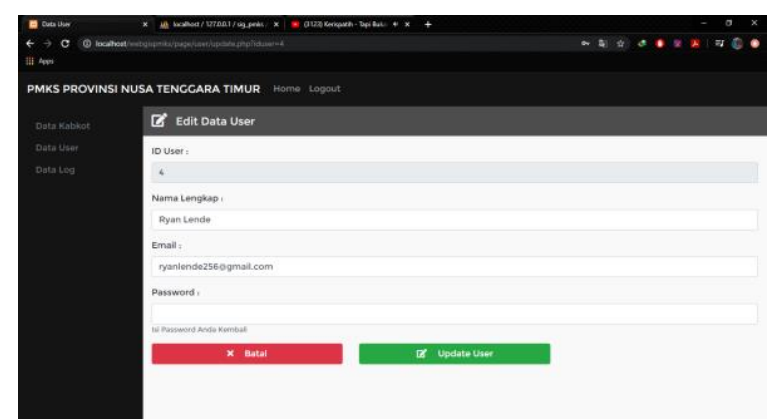

Gambar 17 Halaman Edit Data User

Hasil dari program untuk tampilan pada halaman Data Kabkot dapat ditunjukkan dalam Gambar 18.

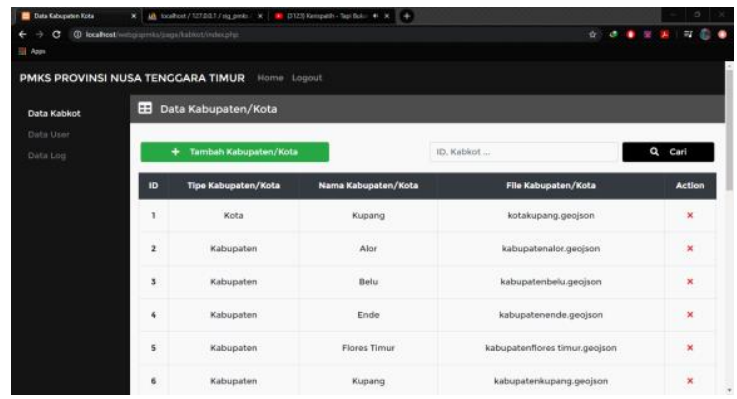

Gambar 18 Halaman Data Kabkot

Hasil dari program untuk tampilan pada halaman Tambah Data Kabkot dapat ditunjukkan dalam Gambar 19. 


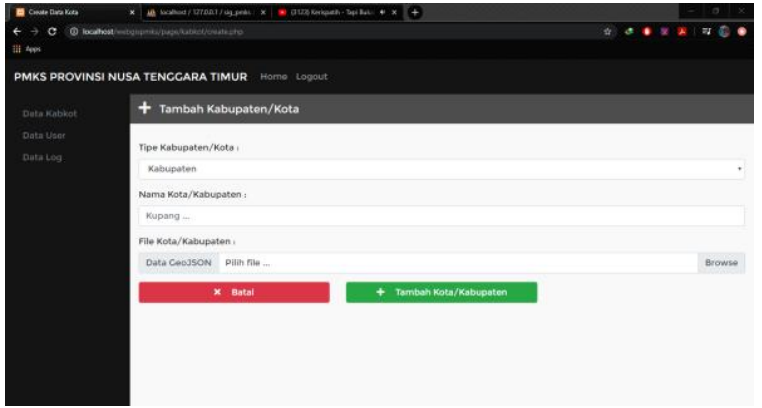

Gambar 19 Tampilan Tambah Data Kabkot

Hasil dari program untuk tampilan halaman Data Log dapat ditunjukkan dalam Gambar 20.

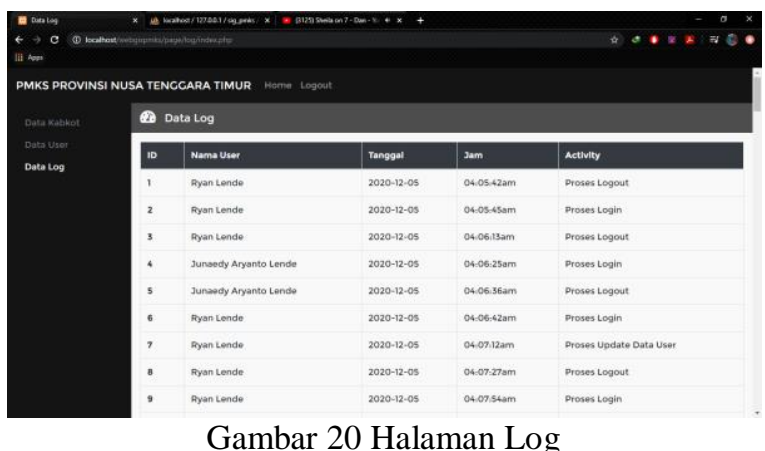

\subsection{Pengujian Fungsional}

Pengujian fungsional dilakukan untuk mengetahui apakah fungsi sudah sesuai dengan kebutuhan atau belum. Pengujian ini juga dilakukan untuk mengatasi error dan menguji validation yang seringkali dilakukan tidak sesuai dengan ketentuan penggunaan aplikasi. Tabel 1 adalah pengujian fungsi menggunakan desktop computer sebagai bahan uji.

Tabel 1 Pengujian fungsi menggunakan desktop komputer

\begin{tabular}{|c|l|c|c|c|}
\hline Hak & \multirow{2}{*}{ Akses } & Fungsional & \multicolumn{3}{|c|}{ Browser } \\
\cline { 2 - 5 } & Home & Chrome & Edge & Opera \\
\hline \multirow{5}{*}{ User } & Cari Peta & OK & OK & OK \\
\cline { 2 - 5 } & Info Peta & OK & OK & OK \\
\cline { 2 - 5 } & Tampil Peta & OK & OK & OK \\
\hline \multirow{5}{*}{ Admin } & $\begin{array}{l}\text { Tambah } \\
\text { User }\end{array}$ & OK & OK & OK \\
\cline { 2 - 5 } & Edit User & OK & OK & OK \\
\cline { 2 - 5 } & Delete User & OK & OK & OK \\
\cline { 2 - 5 } & Tampil User & OK & OK & OK \\
\cline { 2 - 5 } & Cari User & OK & OK & OK \\
\cline { 2 - 5 } & $\begin{array}{l}\text { Tampil } \\
\text { Kabkot }\end{array}$ & OK & OK & OK \\
\cline { 2 - 5 } & $\begin{array}{l}\text { Tambah } \\
\text { Kabkot }\end{array}$ & OK & OK & OK \\
\cline { 2 - 5 } & Cari Kabkot & OK & OK & OK \\
\cline { 2 - 5 } & $\begin{array}{l}\text { Hapus } \\
\text { Kabkot }\end{array}$ & OK & OK & OK \\
\hline
\end{tabular}

Fungsional $100 \%$ sudah berjalan sesuai dengan kebutuhan aplikasi yang dilakukan oleh browser Chrome, Edge, dan Opera.

\subsection{Pengujian BlackBox}

Pengujian balckbox dilakukan untuk mengetahui apakah antarmuka sistem dapat berjalan sesuai dengan desain yang telah dilakukan.

Tabel 2 Pengujian BlackBox

\begin{tabular}{|c|c|c|}
\hline $\begin{array}{l}\text { Skenario Uji } \\
\text { \& Masukan }\end{array}$ & Respon Keluaran & Hasil \\
\hline Tampil Peta & $\begin{array}{l}\text { Peta dapat di load } \\
\text { setelah ada peng- } \\
\text { input-an data peta } \\
\text { dari admin, } \\
\text { membutuhkan } \\
\text { internet untuk me- } \\
\text { load peta dari } \\
\text { openstreetmaps. }\end{array}$ & $\begin{array}{l}{[\checkmark \text { ] Diterima }} \\
{[\text { ] Ditolak }}\end{array}$ \\
\hline Cari Peta & $\begin{array}{l}\text { Peta yang tersimpan } \\
\text { dapat tampil sesuai } \\
\text { dengan key. }\end{array}$ & $\begin{array}{l}{[\checkmark \text { ] Diterima }} \\
{[\text { ] Ditolak }}\end{array}$ \\
\hline $\begin{array}{l}\text { Tampil Peta } \\
\text { Aktif }\end{array}$ & $\begin{array}{l}\text { Peta yang aktif } \\
\text { dapat tampil dengan } \\
\text { baik, peta juga } \\
\text { dapat } \\
\text { disembunyikan. }\end{array}$ & $\begin{array}{l}{[\checkmark \text { Diterima }} \\
{[\text { ] Ditolak }}\end{array}$ \\
\hline Kategori Peta & $\begin{array}{l}\text { Peta dapat berwarna } \\
\text { sesuai dengan } \\
\text { parameter nilai } \\
\text { yang ditetapkan. }\end{array}$ & $\begin{array}{l}{[\checkmark \text { ] Diterima }} \\
{[\text { ] Ditolak }}\end{array}$ \\
\hline $\begin{array}{l}\text { Input Data } \\
\text { User }\end{array}$ & $\begin{array}{l}\text { Input data user } \\
\text { dapat berjalan } \\
\text { dengan baik, } \\
\text { terdapat validation, } \\
\text { dan alert yang } \\
\text { dapat berjalan } \\
\text { dengan baik. }\end{array}$ & $\begin{array}{l}{[\checkmark] \text { Diterima }} \\
{[\quad] \text { Ditolak }}\end{array}$ \\
\hline $\begin{array}{l}\text { Edit Data } \\
\text { User }\end{array}$ & $\begin{array}{l}\text { Edit data user dapat } \\
\text { berjalan dengan } \\
\text { baik, dan alert yang } \\
\text { dapat berjalan } \\
\text { dengan baik. }\end{array}$ & $\begin{array}{l}{[\checkmark \text { ] Diterima }} \\
{[\quad] \text { Ditolak }}\end{array}$ \\
\hline $\begin{array}{c}\text { Hapus Data } \\
\text { User }\end{array}$ & $\begin{array}{l}\text { Hapus data } \text { user } \\
\text { dapat berjalan } \\
\text { dengan baik, dan } \\
\text { alert yang dapat } \\
\text { berjalan dengan } \\
\text { baik. }\end{array}$ & $\begin{array}{l}{[\checkmark \text { ] Diterima }} \\
{[\quad] \text { Ditolak }}\end{array}$ \\
\hline $\begin{array}{l}\text { Cari Data } \\
\text { User }\end{array}$ & $\begin{array}{l}\text { Cara data } \text { user } \\
\text { dapat berjalan } \\
\text { dengan baik, } \\
\text { seluruh data yang } \\
\text { dicari dapat tampil } \\
\text { didalam tabel yang } \\
\text { dibuat. }\end{array}$ & $\begin{array}{l}{[\checkmark \text { ] Diterima }} \\
{[\quad] \text { Ditolak }}\end{array}$ \\
\hline $\begin{array}{l}\text { Tampil Data } \\
\text { Kabkot }\end{array}$ & $\begin{array}{l}\text { Tampil data kabkot } \\
\text { dapat berjalan } \\
\text { dengan baik, } \\
\text { seluruh data dapat } \\
\text { tampil didalam } \\
\text { tabel yang dibuat. }\end{array}$ & $\begin{array}{l}{[\checkmark \text { ] Diterima }} \\
{[\quad] \text { Ditolak }}\end{array}$ \\
\hline $\begin{array}{c}\text { Tambah Data } \\
\text { Kabkot }\end{array}$ & $\begin{array}{l}\text { Input data kabkot } \\
\text { dapat berjalan } \\
\text { dengan baik, } \\
\text { terdapat validation, } \\
\text { dan alert yang } \\
\text { dapat berjalan }\end{array}$ & $\begin{array}{l}{[\checkmark \text { Diterima }} \\
{[\text { ] Ditolak }}\end{array}$ \\
\hline
\end{tabular}




\begin{tabular}{|c|c|c|}
\hline $\begin{array}{l}\text { Skenario Uji } \\
\text { \& Masukan }\end{array}$ & Respon Keluaran & Hasil \\
\hline & dengan baik. & \\
\hline $\begin{array}{l}\text { Hapus Data } \\
\text { Kabkot }\end{array}$ & $\begin{array}{l}\text { Hapus data kabkot } \\
\text { dapat berjalan } \\
\text { dengan baik, dan } \\
\text { alert yang dapat } \\
\text { berjalan dengan } \\
\text { baik. }\end{array}$ & $\begin{array}{l}{[\checkmark] \text { Diterima }} \\
{[\quad] \text { Ditolak }}\end{array}$ \\
\hline $\begin{array}{c}\text { Cari Data } \\
\text { Kabkot }\end{array}$ & $\begin{array}{l}\text { Cari data kabkot } \\
\text { dapat berjalan } \\
\text { dengan baik, } \\
\text { seluruh data yang } \\
\text { dicari dapat tampil } \\
\text { didalam tabel yang } \\
\text { dibuat. }\end{array}$ & $\begin{array}{l}{[\checkmark] \text { Diterima }} \\
{[\quad] \text { Ditolak }}\end{array}$ \\
\hline $\begin{array}{c}\text { Fungsi } \\
\text { Codding }\end{array}$ & $\begin{array}{l}\text { Fungsi coding } \\
\text { keseluruhan dapat } \\
\text { berjalan dengan } \\
\text { baik mulai dari } \\
\text { HTML, PHP, dan } \\
\text { Java Script. }\end{array}$ & $\begin{array}{l}{[\checkmark] \text { Diterima }} \\
{[\quad] \text { Ditolak }}\end{array}$ \\
\hline
\end{tabular}

Pada tabel 2 pengujian BlackBox dimana seluruh fungsi dicek apakah dapat berjalan dengan baik sesuai dengan desain sistem atau sebaliknya, dari hasil pengujian yang dijalankan dapat dinyatakan bahwa sistem telah berjalan $100 \%$ sesuai dengan desain sistem.

\subsection{Pengujian Pengguna}

Pengujian pengguna dilakukan kepada 55 responden dengan kriteria mahasiswa/pekerja swasta, yang nantinya akan sering mnegujungi sistem informasi ini.

Tabel 3 Tabel Hasil Pengujian Pengguna

\begin{tabular}{|c|l|c|c|c|c|c|}
\hline \multirow{2}{*}{ No } & \multicolumn{1}{|c|}{ Pernyataan } & \multicolumn{5}{|c|}{ Penilaian } \\
\cline { 3 - 7 } 1 & SB & B & C & B & BS \\
\hline 2 & $\begin{array}{l}\text { Yampilan website } \\
\text { Kemudisajikan } \\
\text { membaca tulisan }\end{array}$ & 0 & 1 & 4 & 15 & 35 \\
\hline 3 & $\begin{array}{l}\text { Komposisi warna } \\
\text { website }\end{array}$ & 0 & 2 & 7 & 14 & 32 \\
\hline 4 & $\begin{array}{l}\text { Struktur menu yang } \\
\text { disajikan }\end{array}$ & 0 & 1 & 9 & 14 & 31 \\
\hline 5 & $\begin{array}{l}\text { Konsistensi } \\
\text { tampilan layar untuk } \\
\text { setiap menu }\end{array}$ & 0 & 0 & 6 & 20 & 29 \\
\hline 6 & $\begin{array}{l}\text { Kelengkapan } \\
\text { informasi yang } \\
\text { disajikan }\end{array}$ & 0 & 1 & 9 & 14 & 31 \\
\hline
\end{tabular}

Keterangan:

$\mathrm{SB}=$ Sangat Buruk

$\mathrm{B}=$ Buruk

$\mathrm{C}=$ Cukup

$\mathrm{B}=$ Baik

BS $=$ Baik Sekali
Pada tabel 3 pengujian pengguna dapat disimpulkan bahwa 63,6\% menyatakan Tampilan website yang disajikan baik sekali, dan 7,3\% menyatakan cukup. Kemudahan untuk membaca tulisan $72,7 \%$ pengguna menyatakan baik sekali dan 5,5\% cukup. Pada Komposisi warna website dan Struktur menu yang disajikan $25,5 \%$ pengguna menyatakan Baik. Dan untuk Kelengkapan informasi yang disajikan $56,4 \%$ pengguna menyatakan Baik Sekali dan 16,4\% menyatakan cukup. Dengan kata lain, mayoritas pengguna menilai website yang dibuat telah memenuhi kebutuhan.

\section{KESIMPULAN DAN SARAN}

\subsection{Kesimpulan}

Berdasarkan hasil pembahasan penelitian ini yang telah dipaparkan pada bab sebelumnya, maka dapat ditarik beberapa kesimpulan sebagai berikut:

1. Hasil pengujian metode BlackBox dimana menguji seluruh fungsi dapat berjalan sesuai dengan desain sistem.

2. Hasil pengujian fungsional pada desktop menunjukkan bahwa aplikasi SIG dapat berjalan dengan baik di beberapa browser seperti chrome, edge dan opera.

3. Hasil pengujian pengguna menyatakan bahwa mayoritas pengguna menilai tampilan website yang disajikan sudah baik sekali, dan mayoritas menyatakan bahwa informasi yang disajikan sudah lengkap.

4. Aplikasi SIG ini dapat memberikan informasi PMKS kepada pemerintah Provinsi Nusa Tenggara Timur karena data yang disajikan dapat diakses melalui internet.

5. Sistem dapat menampikan Informasi Penyandang Masalah Kesejahteraan Sosial untuk masyarakat dilihat dari informasi yang ditampilkan didalam panel peta.

\subsection{Saran}

Berdasarkan hasil penelitian yang telah diperoleh, didapatkan beberapa saran yang dapat peneliti sampaikan guna perbaikan pada perkembangan penelitian ini dikemudian hari, yaitu:

1. Pengembangan sistem informasi geografis selanjutnya diharapkan dapat mencakup wilayah RT dan RW.

2. Pengembangan sistem informasi geografis selanjutnya diharapkan dapat dikembangkan menggunakan aplikasi mobile.

3. Pengembangan sistem informasi geografis selanjutnya diharapkan dapat ditambahkan fitur Location Based Service.

\section{DAFTAR PUSTAKA}

[1] I. Fachruddin Budiarto, "Sistem Informasi Geografis Sebaran Pondok Pesantren Di Kota Malang," J. Mhs. Tek. Inform., vol. 3, no. 1, hal. 129-135, 2019.

[2] M. Arbina, F. T. Industri, K. Tengah, G. 
Dinas, dan P. Kalimantan, "Sistem infomasi geografis pemetaan daerah perkebunan dan komoditas hasil panen provinsi kalimantan tengah," J. Mhs. Tek. Inform., vol. 3, no. 1, hal. 165-172, 2019.

[3] A. Septya, P. Pradana, dan F. T. Industri, "PRODUKSI TANAMAN PANGAN KABUPATEN KEDIRI JAWA TIMUR," vol. 3, no. 2, hal. 9-15, 2019.

[4] Y. A. Pratama, "Sistem Informasi Geografis Fasilitas Kesehatan Di Kota Batu Menggunakan Metode Location Based Service ( Lbs )," vol. 2, no. 1, hal. 161-166, 2018.

[5] Y. A. Pranoto, M. M. Rokhman, Suryo Adi Wibowo, A. Pemetaan, dan B. W. Website, "Jurnal MNEMONIC Yosep | Miftakhur | Suryo," vol. 1, no. 1, hal. 50-55, 2018.

[6] Julkifli, "Sistem informasi geografis kecamatan woja kabupaten dompu nusa tenggara barat," vol. 2, no. 1, hal. 144-152, 2018.

[7] K. S. BPS, "Penyandang Masalah Kesejahteraan Sosial Indonesia 2011," vol. 12, hal. 1-8, 2011.

[8] K. S. RI, "Pedoman Pendataan dan Pengelolaan Data Penyandang Masalah Kesejahteraan Sosial dan Potensi dan Sumber Kesejahteraan Sosial," hal. 1-7, 2012.
[9] D. Sosial, P. Nusa, dan T. Timur, "BAB I."

[10] A. Aini, "Sistem Informasi Geografis Pengertian dan Aplikasinya," Diakses Dari http//stmik. amikom. ac. id/[Diakses 24 Maret 2013], 2007.

[11] W. Ambarwati dan Y. Johan, "Sejarah Dan Perkembangan Ilmu Pemetaan," J. Enggano, vol. 1, no. 2, hal. 80-82, 2016, doi: 10.31186/jenggano.1.2.80-82.

[12] N. A. F. J. Qolis, "Pemetaan dan analisa sebaran sekolah untuk peningkatan layanan pendidikan di kabupaten kediri dengan gis," hal. 1-5, 2009.

[13] Inolabs, "Pengertian WebGIS," 2016. .

[14] E. J. Tanjaya, S. Rostianingsih, dan A. Handojo, "Pemetaan Surabaya Heritage Dengan Geographic Information System," J. Infra, vol. 4, no. 2, hal. 1-18, 2016.

[15] Y. Herdiana, "Aplikasi Rumus Matematika Sma Berbasis Mobile," J. Ilm. Komput. dan Inform. ( KOMPUTA ), 2014.

[16] B. A. B. Ii, “,2017) Pada 5,” hal. 5-12, 2016.

[17] S. Kawangkoan, N. D. Sekeon, Y. D. Rindengan, dan R. Sengkey, "Perancangan Sig Dalam Pembuatan Profil Desa SeKecamatan Kawangkoan," E-Journal Tek. Elektro Dan Komput., vol. 5, no. 1, hal. 4959, 2016. 